\title{
No Liberation for Harvard Women
}

UNIVERSITIES are rightly proud of the part which they have played in recent years in the advancement of all kinds of liberal causes, such as civil rights for coloured people in the United States, which is why it is ironical that universities should be among the most flagrant exploiters of women in employment. The fact that Harvard University should be the first to make a public confession of its wrongdoing by publishing last month the report of its Committee on the Status of Women in the Faculty of Arts and Sciences is not necessarily a sign that it has more to confess than other universities of similar repute and size; honesty may be a sufficient explanation. But the report does provide a good deal of evidence that the best universities are able, because of the competition which there tends to be for places on the faculty, to keep women teachers in greater humiliation than lesser institutions. The Committee on the Status of Women points out that in 1970, only two out of more than 450 tenured professors were women, that only eleven out of 222 associate and associated professors were women, but that the ranks of the untenured were well populated by women. On the basis of the statistics available, the report infers that "the situation at Harvard is only slightly worse than that at other major universities, and even Berkely is only able to boast that two per cent of its full professors were women in 1970 .

The most serious abuse at Harvard, according to the Committee on the Status of Women, lies in the concentration of such women as find jobs at the university in untenured appointments as lecturers, research associates or research fellows. What happens is that many of the women concerned are unable to leave the area, possibly because of marriage, or are unable to work full-time, as during child-rearing. The university-which in this sense is to be interpreted as the heads of the departments, not simply the administration on which all calumnies are heaped - can snap up academic labour cheaply. But it is well known that untenured posts at universities such as Harvard are regarded by professional academics as stepping stones to tenured appointments either at Harvard or at other universities. People who languish for more than a few years as research fellows are likely to stay that way, and this indeed is what seems to have happened at Harvard. Women in untenured posts have no voice in the university's affairs and little hope of professional advancement.

Old-fashioned prejudice has helped to strengthen this sense of purdah. The report now published has some scarifying tales to tell of the questions which heads of departments, male no doubt, have asked of women applicants for jobs. Do you plan to have children? Will you look after your children yourself? Does your husband intend to stay here or to find a job elsewhere? The report quite properly points out that the assumptions that underlie these questions are unworthy of a university such as Harvard. It also says, without quoting chapter and verse, that many appointments of distinguished women have in the past been blocked by assumptions, implicit or even explicit, that single women academics are in some sense peculiar, that married women academics are merely appendages to the husbands whose careers must come first, that the possibility of children makes all women poor risks and that women, in any case, cannot work full-time.

What is to be done? The particular recommendations of the Committee on the Status of Women are a mixed bag. The committee offers as a goal that the "Harvard Faculty should strive to achieve" a percentage of tenure among women equal to the percentage of women in those collecting PhD degrees at Harvard ten years ago (which is close on ten per cent) and a percentage of women in non-tenure jobs equal to the percentage of women in the cohorts of $\mathrm{PhDs}$ at present graduating. As a basis for what may turn out to be a negotiation, this is sensible enough. It would not, for example, cause too much upheaval in the immediate future, yet it would provide such an influential representation for women in the university's affairs that imbalances elsewhere in the system would be corrected in the course of time. The objection, of course, is that such a numerical goal is bound in some sense to be artificial. And if, as is probable, academic life is less prejudiced against women than the still more iconoclast professions of commerce, politics and the law, is there not at least a chance that women would win more than a strictly proportionate share of faculty positions if they were genuinely in favour of a complete four year tenure post on the basis of their scholarship ? It would, in other words, be more equitable and in the long run more sensible if the university were to enjoin its faculty to deal fairly with all appointments, to lay down the rules to govern the filling of posts and then to let the devil take the hindmost, whatever his (or her) sex.

\section{Years Ago}

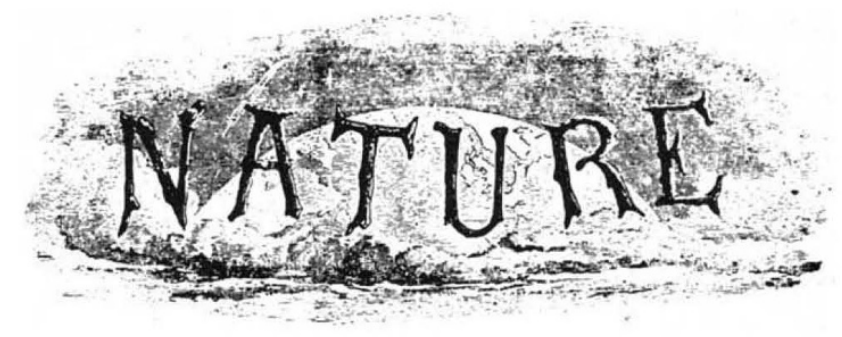

NOTES

IT will be welcome news to astronomers throughnut the world to hear that the Board of Visitors of the Royal Observatory have determined to ask the Government to grant the sum of $5,000 l$. to enable photographic observations to be made of the approaching Transit of Venus. It is a matter of wonder that now, when the labours of De la Rue and Rutherford have brought this most perfect means of astronomical record to a pitch of perfection which it is scarcely needful to surpass, it is still ignored in official observatories. In the matter of the Transit of Venus, it will more than double the chances of success, and Mr. Rutherford has shown that in other inquiries it enables an only moderately skilled person to do in a month what a Bessel would require years to compass by the old method. There is no doubt that the appeal to Government will be successful. Would that we had a Physical Observatory and a Board of Visitors to look after other phenomena which we are now neglecting, the observation of which is even of more importance in the present state of science than that of any number of Transits of Venus ! 